\title{
From the Future
}





\section{SOCCER STEPS IN WHERE POLITICS FAIL TO CREATE A NEW VOCABULARY}

Antjie Krog

University of the Western Cape

On vast screens the opening ceremony of the World Cup 2010 enfolds. With thousands of pedestrians we stand and watch in one of the public spots in Cape Town. The face of praise singer Zolani Mkiva, adorned with porcupine quills, fills the screens. He "praisesings". His rasping yet powerful stentorial voice shudders the ground. Wild applause. Then somebody behind me complains: "Again, the ethnic drum!"

I try not to turn around, but she explains anyway. "We are incapable of imagining ourselves other than in ethnic stereotypes. During the drawing of the teams into different groups, there they were: the Xhosa praise singer, the Zulu warrior, the Venda snake dance, the Basotho stick fight. And Charlize Theron as the Boerefloozy. We are bankrupt!"

But she, actually all of us, was in for a surprise. Suddenly the screen fills with women clad in beautiful blankets. No traditional shaking of breasts or bums, no beads or feathers, but wide, generous

\begin{tabular}{|l|l|l|l|l|}
\hline Ilha do Desterro & Florianópolis & n61 & p. 191- 198 & jul/dez 2011 \\
\hline
\end{tabular}


blankets. Stately the women rock, then gracefully they spread the blankets open for the world to come and sit down with us.

"Look there!" somebody shouts. A big structure is trying to unfold into a recognizable form. On the look-out for stereotyping, we expect nothing else but the ... yawn... African Big Five. But instead of a big and mighty elephant, rhinoceros, lion, buffalo or cheetah, an exquisite enormous dung-beetle wobbles centrestage. Mute with pleasure we turn towards one another. Brilliant! A small un-esteemed insect. "Soccer is in shit!" somebody laughs.

"It's presenting the sun," somebody else shouts. "Think scarab! Think Egypt! Symbol of transformation and revival!" and I suddenly remember the scarab cut from desert glass and put on the heart of Tutankamen to prevent his own heart from turning against him in the Afterworld. We applaud and shout. Our hearts turn to our continent, from the south to the north.

In the last scenes big pieces of colorful cloth with patterns worn daily by ordinary people in African streets and villages, weave together to form the map of the world. We go wild. It is us! We from cloth. We from blanket-spreading. We from the dung-beetle. We from the baobab. The new language to talk about ourselves is becoming visible, but just ... just before we grasp it, a hooded comrade, with all the cameras of the world on him, rises his clenched fist in Black Salute.

\section{$* * *$}

"We are no longer used to see such relentless white men ordering us around," says my husband when we watch Fifa-Führer, Sep Blatter, in full operational mood on television. He wants a new stadium to be built in Cape Town for the semi-final, otherwise the game goes to another city. But we HAVE a stadium that can be upgraded, says the 
television host. No, Blatter wants a new one.

"It will become an expensive white elephant afterwards," I say. "What does he care?" that's my husband. "He himself wants to be televised between the dramatic beauty of Table Mountain and the moral triumph of Robben Island. No World Cup will ever be able to trump that - esthetically or ethically!"

But despite our deepest skepticism and critique, we feel how we are being pulled into a strange and wonderful Prague summer. Soccer is poor and rural in South Africa, so the event immediately draws in support from all black South Africans and left wing whites. Therefore soccer also becomes politically correct. Being dominated by the famous European clubs, the event also gets support from conservative whites-although most of them prefer rugby. "Soccer is so boring to watch," one guy, phoning in, said. "A real sissy game. Actually they're all actors, falling around as if being shot in the spleen. I don't watch, I just ask my wife to shout the score now and then to everybody in the house!"

What has become an unexpected pleasure, is how one is allowed to play "diplomat": during every game we chose who we want to support. Brazil and Argentina are our allies, Ghana and Cameroon our family, Bafana-Bafana our heroes. But halfway one can switch alliances and shout: Spain has stagefright. Germany should pola (thresh) now!"

And as we meet the deadlines and the soccer fans flock in, we also seem to understand that everybody is necessary to make a success of the event: street children and beggars, worker unions and cleaners, politicians and widows, what you have and who you are, counts less than the fact that we as South Africans must be able to rely one hundred percent on one another. 


\section{And see how we pulled it off!}

Cape Town created a "fanwalk". From the refurbished station fans can now walk a freshly laid out 2.5 kilometer to the stadium. It is so successful that people fly in from other cities especially to walk the Cape Town fan walk. Capetonians who live in townships on the outskirts of the city take the trains to walk the walk with the world. Brass bands play ancient slave songs. Somebody swallows fire. We embrace strangers, eat baobab ice cream, celebrate huge colorful puppets along the way and blow the vuvuzela as if it is a human right.

On the newly built pedestrian bridge one can look at the mountain as blue as a gassflame or The Island in a haze of sea-there, always there as our deepest conscience. We find that we begin to laugh a lot, that we look at one another as if we really want to see, really want the other to see that we see them. People begin to "take five" with friendly police people. Even the criminals seem patriotic. "Lowest crime rate ever" read the headlines. "Unions will not strike during World Cup." The city is filled with light and music and goodwill.

A friend writes from Australia. He watched the opening ceremony, but it was preceded by three hours of terrifying documentaries about South African crime, assaults, rapes, killings, xenophobia-"so much concentrated violence I have never seen before on Australian television". Then came Archbishop Desmond Tutu "cheerful, unholy, the beautiful ceremony and the peaceful crowds. The foreign media is South Africa's biggest enemy," he says.

Bafana-Bafana is out! Against all odds the team survived much longer than expected. But the way South African berates them makes my hair stand on end. I am furious. I want to crash-in somebody's 
face on television. I want to roar over a vuvuzela: what the hell did you expect? How on earth do you think one becomes a winner?

Suddenly Bafana is being described as lazy and the trainer accused of using the wrong formation. When Ivory Coast, Nigeria and Cameroon fall out, headlines sternly ask: why do African teams do so pathetically? Phone-ins are abuzz with self-styled couch analyzers.

The Nigerian government forced its whole team to resign and banned them for playing for two years because they have brought shame to the country. One can cry in your hands.

In South Africa's townships one will not find a single properly equipped soccer field nevermind a club. Soccer is not played as part of school sport-in fact there is no such thing as school sport. There are no regular organized school soccer competitive games. There is no talent scouting at school and regional level as is happening in athletics, rugby and cricket. A boy in the rural areas who plays good soccer has as much a chance of being spotted as a blue spot on Uranus.

So without proper nutrition, a soccer ball, a field with goal posts, or coaching, a South African team, probably chosen from only $5 \%$ of the country's population, has to beat the world's top teams. And why not? South Africans seem to ask. We have become used to troubleless and toil-less miracles. Magical wands. What is Mandela but an ordinary cattle herder and jailbird? What is Tutu but an ordinary township kid and polio-victim? And look where they are! Miracles are our birth right. We demand to be winners without any kind of effort, sacrifice, patience, resources or planning.

One wants to suffocate television programs like Idols and Big Brother because they are contaminating communities with the belief that you CAN become rich and famous if you are arrogant enough to force your thick-skinned talentless-ness on a spunkless public too lazy to WORK with self-respect for deserved honour. 
"We should not make excuses for Bafana," says one sport journalist, "this will be condoning mediocrity." I want to rub fly shit in his hair. Also on the suits of those politicians who only speak in parliament if they can complain about the amount of whites in a team, while never even whispering a word about the criminal ways black soccer potential goes to waste in townships as soccer bosses guzzle all the money. Where are the conversations with the brilliant Third World countries in South America? Are we not interested in how Brazil managed to be so remarkable in soccer?

When the Ghanian team fell out, one of their soccer heroes said on television that it was the will of God. I want to say: may God help African soccer to realize that God best helps those who help themselves.

It ended, the madness. At last. The fireworks is over, and as the vuvuzela sounds become less, so the noise of politicians grow louder and we return to our desperate selves extradited to leaders without a vision.

But let me first confess. After the second last match, I suddenly realized that one hardly saw any women during these frantic weeks and I scolded myself for not noticing it earlier. We have all actually been drenched by men. If they don't stand mute hanging on to one another, they sing their anthems with wild pent-up veins in their necks; if they don't have mom's-darling-son's-highlights, they have polished shining heads, if their mouths are not yelling into the face of a slow-on-the-uptake referee, they spi-yes, the soccer fields must have been one piece of slippery sloppy slime.

And then there were the trainers with their light grey suits clearly all made in the same factory. The one trainer looks as if he 
was caught somewhere in Slovakia and right through the event he seemed puzzled about where he got his tie from. The German trainer looked like a maniacal ski-instructor out of The Bold and the Beautiful. And of course Maradona, as fleshy as a big toe, with the bright mongoose face of Messi. The Spanish trainer looked as if he had been eating grass downhill most of his life. For weeks we had no women on the television screen (except once for Angela Merkel and the beauties carefully picked from the crowds by the cameramen). No female media person, line judge, doctor or sport commentator. No, the message is clear: soccer is for men, real men.

The behavior of my fellow citizens during the World Cup tore away at my heart. We were clearly starved to death to unite behind an inclusive vision. We were yearning to feel one with one another as we did when we made our crosses in our first democratic election. Although the crosses were equal in worth, we all realized that a win for democracy was not going to wipe out the inequality among ourselves-yet we were united in our willingness to accept each others as equal and fellow South Africans.

But instead of working towards a more equal society, we pointed to unbridgeable divides, the politicians deftly helped to create more of them. We became a country who agreed on nothing, except Nelson Mandela. Everything we tackled exposed us as heartbreakingly divided in terms of race and class.

But then came Fifa. They confronted us with a belief in our capacity, then put forward a vision, proposed a plan and put a deadline. And didn't we perform! No strikes, no excessive price increases, no electricity failures. We managed to deliver on time: the stadiums, the roads and transport to the stadiums, every game started exactly on its allotted time because the teams were there, the referees, the spectators. Actually a true miracle. 
In terms of reconciliation, Ron Kraybill has identified several steps within a reconciliation cycle after two groups have harmed one another: the first step is a turning away from one another in order to re-define oneself. ("The Cycle of Reconciliation" Conciliation Quarterly 14 number 3, Summer 1995). Am I only a racist white? Am I nothing more than a harmed black victim? After the re-defining, the second step is called the undertaking of "a small act of trust" in which both groups take a risk with each other. If the risk pays off, then a new re-definition is called for: I am more than a black victim, I can also pull off a world class event. This process of redefining and trusting have to be repeated again and again, because the more reconciled a country becomes, the more its structures will begin to benefit everybody. Research has found that in countries where people were not allowed to redefine themselves, or failed during acts of trust, groups then solidified into intransient entities functioning in destructive ways that prevented citizens from fully accessing the advantages of a democratic state.

Our first democratic election was South Africa's first act of trust. The Soccer World Cup probably our second. We haven't failed one another. But do we dare redefine ourselves when our math education has been rated lowest on the continent and there is as yet nothing put in place to check that the two billion rand made by South African soccer bosses from the World Cup is spent on the development of soccer in South Africa?

How long are we to stay "a tale of two cities"? 